\title{
Three Religious Movements' Impact on Thai Buddhism
}

\author{
Liu Meiwu* \\ International Business School \\ Yunnan University of Finance and Economics \\ Kunming, China \\ lmwkm11@sina.com
}

\author{
Chen Weilin \\ The Faculty of Arts \\ Chulalongkorn University \\ Bangkok, Thailand \\ cw193523cc@gmail.com
}

\begin{abstract}
As the process of modernization on the part of Thailand continued, changes, division and even conflict took place in different religious movements. Whether in time span or social influence, these three religious movements as Suan Mokh, Dhammakaya and Santi Asoke were significant reflected the transformational trends of relationship between modern society and Buddhism in Thailand. This paper argues that these three movements have brought different but also important impact on Thai Buddhism respectively.
\end{abstract}

Keywords-Thai Buddhism; religious movement; political process; society operation

\section{INTRODUCTION}

Since the King Mongkut was put religious reforms into force in 1830s, not only the subsequent rulers has constantly balanced the relationship between Sangha and state politics, the different sects of Thai Buddhism but also adjusted their role during the last two centuries. The process of globalization, modernization, urbanization and immigration wave which promote the development of Thailand also determined the development trend of Thai Buddhism to some extent. Mutually, Thai Buddhism as an important ideology surely would exert influence on contemporary society operation and political process of Thailand.

Whether the early religious movement of Suan Mokh which initiated by Buddhadasa Bhikkhu in 1932 or the later movements of Santi Asoke and Dhammakaya in 1970s were not by accident but closely linked with the social situation and reflected the corresponding collective demands of certain groups.

In addition, these three religious movements of Thailand also gain the attention of both western and Thai scholars. Professor Suwanna point out that these three movements are basically reformist attempts to make Buddhism meaningful to modern life, both as critique and affirmation. All three carry enormous potential for change, both for the future of Buddhism in Thailand and for the struggle of the Buddhist religion in the modern world [1]. Peter Jackson analysis of these movements reflects an in-depth understanding of Thai sociopolitical scene [2]. Donald Swearer regards both Santi Asoke and Dhammakaya as examples of Buddhist fundamentalism. Fundamentalistic religious groups share three major elements: a commitment to the authority of scriptures, a concern for

\footnotetext{
* Corresponding author
}

orthodox beliefs and a history of involvement with the state [3].According to Rory Mackenzie, he suggest that the existence of Wat Phra Dhammakaya and Santi Asoke indicate that a section of the people are disenchanted with mainstream Thai Buddhism, yet do not want to abandon Buddhism. The two movements have offered teaching, lifestyle and practice in keeping with the aspirations of their followers [4].

However, most of the research on these movements has taken place in the early 1990 s and early 2000s. Because of the difference of social background, most of scholar did not directly make a comparison among three movements. In my point of view, the key factor which could determine the effect degree of above religious movement is not only laid on what idea these movements advocated but also depended on the acceptability and accessibility of ordinary public in Thailand nowadays. The impact of above religious movements on Thai Buddhism has tightly combined with different social sectors. Hence, based on the literature review and internet recourses, this paper will through three perspectives as "Group Impact", "Intellectual impact", and "Political impact" to probe why each three religious movements could brought different impact on Thai Buddhism respectively.

\section{GROUP IMPACT: THE LAY FOLLOWER IN MODERN THAILAND}

The common definition of religious movements are normally interpreted as a group of people or a community with a common ideology who try to achieve certain general goals and intended to bring about religious reforms. Compared with the lay follower formation of Buddhadasa, the collective identity of lay follower in Dhammakaya and Santi Asoke is more distinctive and distinguishable from ordinary group. And as the rising role of the lay follower in Thai Buddhism, the social status and collective symbols of their corresponding follower also as a crucial factor that reflected the social influence of these sects. And it also could reflect their economic impact to some extent. In the common perspective, the follower and participator of Dhammakaya generally depicted as middle class who is well educated, economically better-off urbanites, bureaucrats and high-ranking enterprise.

As regard to Santi Asoke, the collective identity of the Sangha and lay follower is generally depicted as a group in terms of strict vegetarian, new middle class, political activists 
and the advocates of organic life style. What worth to mention that the different collective symbols of Santi Asoke's lay follower has showed in the way of sharp contrast. On the one hand, the collective image they devoted to presented for public was a group of morally pure, indifferent to fame and fortune. And they also insist ascetical and organic principle for their lifestyle. On the other hand, they were actively take part in the political conflicts of Thailand since they set up in 1970s. And under the over-exaggerating reports of mass media and relevant political party, they were usually depicted as an illegal, controversial and even aggressive religious group. The embodiment of the contradiction in the group image of Santi Asoke's lay follower helps them attracted the laity who have strong sense of identity. What unites the wings is their selfidentification as disciples of Bodhiraksa [5]. However, it is also hard to accept by the Buddhist or ordinary public who has hold opposite standpoint of Buddhism doctrine, social idea and even political orientation.

Because the social class division was deeply rooted in Thai society and obviously reflected in the uneven social structure of wealth distribution. To some extent, if each religious movements or sects have over-concentrated in express the demands for certain social groups it will undoubtedly intensify the gap and conflict among different social group. In contrast, the movement of Suan Mokh did not over-emphasis the identities of their lay follower and even organization itself. The viewpoint what I want mention in this paper is that the unintense collective characteristic of Buddhadasa's lay follower has laid a crucial foundation of laity formation in modern Thai Buddhism. In contrast with the later religious movements as Dhammakaya and Santi Asoke, the broadly based of Suan Mokh's lay follower also could related with their un-intense collective characteristic. Considered to the early social structure of Thai society, Suan Mokh has deeply influenced each social class. And the movement of Suan Mokh has built the strong connection between Thai Buddhism tradition and the daily life of ordinary public. Based on the group structure and identity of lay follower, it also could demonstrate that Suan Mokh has brought long term impact on Thai Buddhism whether in time span or the number of laity. Although the two later religious movements also bring strong shock for Thai Buddhism, they are in large degree developing form the foundation which lay by Suan Mokh. And with the refining of the structure of social group in Thai society, this phenomenon will not only reflect in the religious movements but also appeared in political movement.

\section{INTELLECTUAL IMPACT: INTERPRETATION, PRACTICE AND ACCEPTABILITY}

Although the interpretation of "Empty Minds" and Abhidhamma has gain a lot debates form traditional Thai Buddhism sects in Thailand, it is no doubt that Buddhadasa was one of the successful Buddhist preachers who explained abstract and complex Buddhist doctrines in an understandable way for the majority of Thai Buddhists since last century. Buddhadasa was intelligently applied it into his interpretation that inspired people to acquired deeply self-understanding and even philosophical thinking of their living condition. This is a very crucial reason that Buddhadasa and his lecture could attract a large number of faithful lay followers.
Similarly, whether in their interpretation of Buddhism doctrine or critical method of Buddhism learning, the Santi Asoke has mainly followed the mainstream teaching of Buddhadasa. Although Bodhiraksa have criticizes Buddhadasa for showing the way to reach nibbana in practical term, the basic principles interpretation of Buddhism doctrine by Bodhiraksa are radically follow the Buddhadasa. This is could demonstrate that the early influence of Suan Mokh movement has deeply impact on the Santi Asoke.

As regard for Dhammakaya, in the three Dhammakaya traditions in Thailand, nibbana is described "as a permanent blissful realm where the Buddha and other enlightened ones reside after death". Nevertheless, for most ordinary Thai people, nibbana still is an abstract conception and remote goal. The quest for merit in order to have a better rebirth seems a more attractive option than enduring the demands placed on the one seeking enlightenment [6]. The movement of Dhammakaya was precisely combined the modern life style of laity with above phenomenon of Thai society, aimed at teaching their follower how to achieve good results by a quickly process of merit making. Hence, the interpretation of Buddhism doctrine in Dhammakaya is also simplistic relative to the commercial objectives.

Based on the perspective of doctrine interpretation in three movements, the interpretation of Buddhism doctrine by Buddhadasa is seems more conservative, but it also adheres to the early religious formation of Buddhism. Both movements as Dhammakaya and Santi Asoke have reflected the feature of fundamentalism to some extent. Look at the practice preference of three religious movements, Dhammakaya and Santi Asoke also has their own intense stand point. Considered to the modern trend of globalization in Thailand, it unavoidable derived different social group in Thai society no matter they gathered by what kind of motivation. Back to the Thai Buddhism itself, one of most crucial reason that could maintain the Buddhism's vitality in Thai society for such a long time span is it accessibility and acceptability of masses. In my point of view, this is also as a key factor could explant why Buddhadasa could gain highly favorite and respect from majority of Thai Buddhist. Even though it still has some limitation existed in the movement of Suan Mokh, the Suan Mokh has played an indispensible role not only inspired people to acquired deeply self-understanding and philosophical thinking of their living condition, but also deeply impacted on the later religious movements in Thailand.

\section{Social Engagement IN THE MODERN THAILAND}

Whether in early period religious reform or later new religious movements, there is no doubt that Thailand have been through a rapid transformation process of Buddhism sect formation during last century. As the one of most important religious movements in Thailand, Buddhadasa have not emphasis the function of organization itself. Hence, Suan Mokh has in large degree to plays the role of being the center of Buddhadasa's spiritual representative rather than a simple physical structure. Compare with the later religious movements as Santi Asoke and Dhammakaya, the social engagement of Buddhadasa and his follower were mainly concentrated in ideas propagation. In the early period of 1940 s, he was invited 
by various prestigious educational institutions in Bangkok and various hospitals and temples to give sermons. Subsequently, Thailand has led by phenomena that a large quantity of press and local organization were produced a large number relevant books of Buddhadasa's teaching. Look at the social structure and situation of postwar period in Thailand and consider to the traditional role of the religious group and the conservative perception of ordinary public, the social engagement of Buddhadasa were basically focus on the above aspects. In addition, according to the perspective of Phra Nicholas, he mentioned that Thai practice was following a strong leader who is perceived to have merit, Suan Mokh which was built up through the scholarship and teaching of Buddhadasa went into decline when Buddhadasa passed away. In other words, there is no doubt that the impact of Suan Mokh on Thai Buddhism has laid a crucial foundation of later religious movements in Thailand. To some extent, however, the social influence of Buddhadasa also inevitably would influence by above reason. The whole 1990s is a key period for the development of two new religious movements in Thailand. Especially around 1997, it is a crucial turning point that both movements as Santi Asoke and Dhammakaya have built social influence in Thai society. Therefore, the role of social engagement of Suan Mokh movement was served as a link between past and future in modern Thai Buddhism.

As regard to Santi Asoke, the leader Bodhiraksa and his lay follower were active involvement in a series of political events. The group of Santi Asoke had a complex relationship to Chamlong Srimuang and Thaksin Shinawatra. And they also have played a controversial role for Thailand political turmoil during the period from 1997 to 2012. Moreover, the Asoke group under the influence of base communities that advocates new approaches to Buddhism economics, organic management and education. Santi Asoke seeks to bring Thai people back from individualistic, materialistic lifestyles to a possessionrenouncing community approach based on Buddhist principle [7]. But these it also challenge the Thai Buddhism tradition in large degree. By contrast, even though the social effect, social networks and social capital that Dhammakaya group has represented are obvious powerful than other sects, they are more focus on how through the self-improvement to build social influence rather than political participation. They are actively involved in promoting their social networks, educational institution and humanitarian aids program. It seems that Dhammakaya group put into emphasis the social function and social responsibility of a new Buddhist organization, but the complex social networks which behind the Dhammakaya has deeply rooted in contemporary Thai society.

From the perspective of social engagement, the both sects as Santi Asoke and Dhammakaya have challenged the traditional formation of Thai Buddhism, and it also reconstructed the inherent definition of sect's social function for most ordinary Thai people. Although the two later religious movements has bring strong social debates whether in their motivation or social engagement, these phenomena also reflected the development dilemma that Thai Buddhism have to face in modern Thailand. As the results of long term political unrest and the failure process of democratization that contemporary Thai society has full of the inherent social problem and a series of new social problem has continuing emerging. Hence, the social engagement of religious group also have played an crucial role that directly or indirectly impress the political demands for the certain social group which behind the back of religious movements.

\section{CONCLUSION}

Buddhism has long served as one of the most important source of political legitimation, socializing, acculturating, and unifying forces in Thai society. It has profoundly influenced the cultural, economic and political development of the Thai nation. Whether in time span or the foundation of lay follower, the accessible intelligence of Buddhadasa has broughtthe most important long term impact on Thai Buddhism. The movements of Suan Mokh not only inspired people to acquire deeply self-understanding and philosophical thinking of their living condition, but also led the new Buddhism ideological trend from the quantitative to qualitative change In Thai Buddhism. Moreover, the movement of Suan Mokh also was served as a link between past and future in modern Thai Buddhism. The development of later religious movements as Santi Asoke and Dhammakaya also reflected the transformational relationship between modern society and Buddhism in Thailand. Meanwhile, these phenomena also indicate the new develop trend of religious movements in Thailand.

In addition, the three religious movements also indirectly reflected the conscious demands of certain social group. The religion belief is based on the consciousness of identity. However, as the results of unstable social foundation and long term political unrest, the religious movements inevitably have played various social roles. The new trend of religious movements in Thailand was a mirror that reflected the different group demands of social engagement. Thai people through these religious movements to debate and looking for the recognition in order to find the way out of Thai Buddhism in modernization process. Under the unsuccessful democratization process, this new trend also indicate that Thailand have continuing seeking and exploring the balance relationship between religion development and political restructuring. And with the integration and division among various social ideology in future Thai societies, the existence of religious movements will become more significant.

\section{ACKNOWLEDGMENT}

This research paper was partially supported by International Business School, Yunnan University of Finance and Economics. We thank our colleagues from International Business School and Bangkok Business School who provided insight and expertise that greatly assisted the research, although they may not agree with all of the interpretations of this paper.

We would also like to show our gratitude to the moderators for sharing their pearls of wisdom with us during the course of this research. And we also immensely grateful to reviewers for their comments on an earlier version of the manuscript. In addition, we would also thank peer reviewer for comments that greatly improved the manuscript.

Last, but not least, We recognize that this research would not have been possible without the financial assistance of the 
University of Finance and Economics, and other institutions, and express my gratitude to those agencies.

\section{REFERENCES}

[1] Satha-anand, and Suwanna, "Religious Movements in Contemporary Thailand," Asia Survey, vol. 30, 1990, pp. 395-407.

[2] P.A. Jackson, "Witherin Center, Flouring Margins: Buddhism's Changing Political Roles," in K Hewison (ed.) Political Chang in Thailand, London: Routledge, 1997, pp. 75-93.

[3] D.K. Swearer, "Fundamentalistic Movements in Theravada Buddhism," in M Marty and RS Appleby Fundamentalisms Observed Chicago: University of Chicago Press, 1991, pp. 90-628.

[4] Rory Mackenzie, "New Buddhist Movements In Thailand: Towards an understanding of Phra Dhammakaya and Santi Asoke," New York: Rutledge, 2007, pp. 187-187.

[5] M.L. Heikkilä-Horn, "Santi Asoke Buddhism and the Occupation of Bangkok International Airport," ASEAS, vol. 3, 2010.

[6] Rory Mackenzie, "New Buddhist Movements In Thailand: Towards an understanding of Phra Dhammakaya and Santi Asoke," New York: Rutledge, 2007, pp. 98.

[7] M. Rory, "New Buddhist Movements In Thailand: Towards an understanding of Phra Dhammakaya and Santi Asoke," New York: Rutledge, 2007.
[8] P.A. Jackson, "Buddhadasa: Theravada Buddhism and Modernist Reform," in Thailand, Chiang Mai: Silworms, 2003.

[9] M.L. Heikkilä-Horn, "Buddhism with Open Eyes: Belief and Practice of Santi Asoke," Bangkok: Fah Apai Co, Ltd. 1997.

[10] M.L. Heikkilä-Horn, "Two Paths to Revivalism in Thai Buddhism: The Dhammakaya and Santi Asoke Movements' in Temenos," vol. 32, 1996, pp. 93-111.

[11] C. Kate. "Theravada Buddhism: Continuity, Diversity, and Identity," Chichester, West Sussex, UK: Wiley Blackwell, 2014.

[12] Rory Mackenzie, "Black to the Basics of Buddhism: The Santi Asoke Movement," in CH Partridge Fundamentalisms Carlisle: Paternoster Press, 2001, pp. 54-173.

[13] Payulpitack, and Suchira, "Buddhadasa's movement: an analysis of its origins, development and social impact," Bielefeld (Germany): Bielefeld University, 1991.

[14] Satha-anand, Suwanna, "Buddhadasa's Challenges: Towards modern Buddhism in Thai society," International Conference on Thai Studies. London, United Kingdom, 1993.

[15] D.K. Swearer, "The Buddhist world of Southeast Asia," Albany: State University of New York Press, 2010.

[16] J. Taylor, "Buddhist revitalization, modernization, and social change in contemporary Thailand," Sojourn, vol. 8, 1993, pp. 61-91.

[17] Tomomi, "Modern Thai Buddhism and Buddhadasa Bhikkhu: A social history," Singapore: NUS Press, 2012. 